\title{
ИСЭГ ЦАГААН ИДЭЭНЭЭС ЯЛГАСАН СУУН ХУЧЛИЙН БАКТЕРИЙН ШИНЖ ЧАНАРЫН СУДАЛГАА
}

\author{
Б.Хандсүрэн ${ }^{1 *}$ Ш.Дэмбэрэл ${ }^{2}$, Ж.Дүгэрсүрэн \\ 1. Мал эмнэлгийн сургууль, Монгол улс \\ 2. Мал эмнэлгийн хүрээлэн, Монгол улс \\ * Цахим шуудан: khanduul@yahoo.com
}

\section{ХУРААНГУЙ}

Монгол малчдын уламжлалт аргаар бэлтгэсэн исгэлэн сүҮн бүтээгдэхүүн болох гүҮний айраг, үхрийн тарагнаас сүҮн хүчлийн савханиар ялган авч түҮний пробиотик шинж чанарыг in vitro орчинд судаллаа. ЭнэхүҮ судалгааны дүнд иинж чанараараа бусдаасаа давуу байсан 44c өсгөвөр нь Монголд айрагнаас ялгасан омог КT368987 болох Lactobacillus helveticus (L.helveticus) зүйлтэй 100\%, 65b өсгөвөр нь Говь-Алтай аймагт ингэний хоормогноос ялгасан омог СР016393 болох Lactobacillus delbreuckii subsp. bulgaricus (L.bulgaricus) зүйлтэй 99\% төстэй байлаа. Гарган авсан сүҮн хүчлийн савханирууд нь малын Escherichia coli (E. coli) 09, E. coli 026, Salmonella abortusovis (S. abortusovis) 0068 болон хүн амын дунд тархсан Staphylococcus aureus (S. aureus) 5695, S. aureus 5068, S. aureus SA27, E.coli 10963, E.coli 10977 зэрэг ходоод гэдэсний эмгэг төрүҮлэгчдийн ургалтыг бүрэн дарангуйлж байв. Тэдгээрийг зохииуулах үйлчилгээтэй хүнсний бүтээгдэхүүний үйлдвэрлэлд хэрэглэх омогт тавигдах үндсэн шалгуурууд болох хоол боловсруулах замын хүчиллэг орчныг тэсвэрлэх болон өргөн хэрэглээний антибиотикуудтай хавсран хэрэглэхэд идэвхээ алдахгүй байх чанаруудыг судлан тогтоолоо.

Туршилтын дүнгээс харахад амьдрах орчны рН 4.0 болоод 3.5-д хүрэхэд омгууд 80аас дээщ хувийн ургалттай байснаас гадна пенициллин, аминоглюкозид, иефалоспорин, макролид зэрэг 5 бүлгийн 10 төрлийн антибиотикт харилцан адилгүй мэдрэг чанартай (тэсвэртэй) байлаa. Жишээлбэл: Бүх ашигласан антибиотикийн зээрэниэг L.helveticus

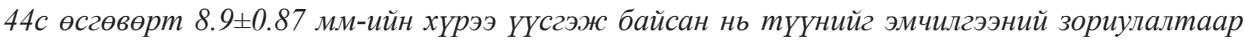
эдгээр антибиотиктэй хослон хэрэглэх боломжтойг батлан харуулж байгаа юм. Эдгээр иинжүүдээс гадна 1 мл-т агуулагдах бактерийн тоог анаэроб нөхиөлд MRS тэжээлт орчинд ургуулж CFU/ml-ийг тогтоосон. L.helveticus 44c-ийн хувьд ургалтын 48 дахь иагтаа 2176 x1010, L.delbrueckii subsp. bulgaricus 65b нь 72 дахь ųагтаa 2503 х 1010 хүрээд эргэн буурах хандлагатай байлаа. Тиймээс эдгээр омгуудыг тухайлбал L.helveticus 44c, L.delbrueckii subsp. bulgaricus 65 омгуудыг пробиотик бүтээгдэхүҮн өөрөөр хэлбэл зохииуулах үйлчилгээтэй бүтээгдэхүуний эх материал болгон ашиглах боломжтой юм.

Түлхүур үге: СУҮн хүчлийн бактери, пробиотик, антогонист идэвх, L.helveticus, L.delbrueckii ssp. Bulgaricus; 


\section{ОРШИЛ}

Дэлхий нийтээрээ эрүүл мэндийн ач холбогдолтой, экологийн цэвэр бүтээгәхүүний нэг төрөл болох ашигтай бактери (пробиотик) агуулсан бүтээгдхүүнийг чухалчлан үзэж, хэрэглээний хүрээ өсч байна. Манай оронд уул бүтээгдэхүүний үйлдвэрлэл, хэрэглээг өргөжүүлж, хэвшүүлэх баялаг эх сурвалж олон байгаагийн дотор монголчууд бидний олон зууныг дамжуулан өнөөг хүртэл уламжлагдаж ирсэн исэг цагаан идээний хөрөнгөний технологи, хэрэглээний соёл [Demberelet al., 2016] томоохон байр суурь эзэлнэ.

Сүүлийн жилүүдэд эмчилгээ сэргийлэлтийн идэвхтэй сүүн хүчлийн бактерийн амьд үржил агуулсан пробиотик бэлдмэлүүдийг хүн, мал эмнэлгийн тэр

\section{МАТЕРИАЛ, АРГА ЗУЙ}

Монгол Алтайн нурууны Казах үндэстний исгэсэн сүүн бүтээгдэхүүнээс авсан дээжийг зөөврийн хөргөгчийн Цельсийн $\quad+20-40 \quad$ хэмд хадгалан лабораторид авчран судалгаанд ашиглалаа. Дээжийг ариутгасан физиологийн уусмалаар 10-5 хүртэл шингэлэн MRS хатуу, шингэн тэжээлт орчинд GasPak систем ашиглан агааргүй нөхцөлд өсгөвөрлөх замаар 112 анхдагч өсгөвөр гарган авч, тэдгээрээс өсгөвөржилт, хэлбэр зүйн хувьд тохиромжтойг нь цэвэршүүлж, пробиотик үйлчилгээний чадавхаар нь сонгон шалгаруулсны эцэст төрөл зүйлийг нь молекул биологийн аргаар тодорхойлон удмын модны зураглал гаргалаа.

Сүүн хүчлийн бактерийн цэвэр өсгөврүүдийг гарган авахдаа сонгомол тэжээлийн хатуу, шингэн орчинд суулгалт хийсний дараа анаэроб контейнерт GasPak систем ашиглан өсгөвөрлөлт явуулсан.

$$
\text { Цэвэр өсгөврүүдийн антагонист }
$$

тусмаа нялх төл, хүүхдийн эмчилгээнд нилээд өргөн ашиглах болсны дээр исгэлэн сүүн бүтээгдэхүүн хэрэглэхийн ач тусыг шинжлэх ухааны өгөгдөхүүнээр баяжуулсаар байна. Эдгээр хэрэгцээ, шаардлагын үүднээс бид төрөл бүрийн исгэлэн сүүн бүтээгдэхүүнээс анаэроб (агааргүй) нөхцөлд сонгомол тэжээлийн орчноор дамжуулан сүүн хүчлийн бактерийг сонгон шалгаруулах замаар пробиотик бүтээгдэхүүнд ашиглах омгуудыг хайх судалгааг явуулсаар байна. Тэдгээрийн дотроос энэ удаад Монгол Алтайн нурууны Казах үндэстний уламжлалт аргаар исгэсэн сүүн бүтээгдэхүүнээс ялгасан сүүн хүчлийн савханцрын биологийн идэвхт шинж чанарын судалгааны үр дүнг толилуулж байна.

идэвхийг төлийн ходоод гэдэсний эмгэг төрүүлэгч E. coli 09, E. coli 026, S. abortusovis 0068 дугаартай нутгийн омгууд мөн хүний ходоод гэдэсний эмгэг төрүүлэгч S. aureus 5695, S. aureus 5068, S. aureus SA27, E. coli 10963, E. coli 10977 дугаартай нутгийн омгуудыг ашиглан цуврал шингэрүүлэлтийн аргаар тодорхойлов.

Хүчиллэг орчинд тэсвэрлэлтийг 3.5 (B) болон 4.0 (C) $\mathrm{pH}$-тай тэжээлт орчинд ургасан колоний тоог эх өсгөврийн (A) колоний тоотой харьцуулах замаар тодорхойлсон.

Антибиотикт тэсвэрт чанарыг Унгар улсын Biolab лабораторид үйлдвэрлэсэн 10 мкг, 15 мкг, 30 мкг антибиотик агуулсан зээрэнцгийг ашиглан Кирби-Бауэрийн диск нэвчүүлэлтийн аргаар тодорхойлов. Зээрэнцгийн эргэн тойронд бичил биетний өсөлт саатсан хүрээг зээрэнцгийн диаметрийг оролцуулан хэмжиж ангиллын дагуу үр дүнг тооцов. 
ХУснэгт 1. Судалгаанд ашигласан антибиотикийн жагсаалт

\begin{tabular}{lll}
\hline \multicolumn{1}{c}{ Антибиотикийн бүлэг } & \multicolumn{1}{c}{ Антибиотикийн нэр } & Товчилсон нэр \\
\hline \multirow{2}{*}{ Пенициллин } & Amoxicillin & AX30 \\
& Amoxicillin+Clavulanic acid & AMC30 \\
(Пенициллин хосолсон) & Ampicillin & AM10 \\
& Ampicillin+Sulbactam & SAM30 \\
Аминоглюкозид & Gentamicin & CN15 \\
\hline \multirow{2}{*}{ Цефалоспорин } & Cefazolin & CZ30 \\
\hline \multirow{2}{*}{ Макролид } & Erythromycin & E15 \\
\hline \multirow{2}{*}{ Бусад } & Clarithromycin & CLR15 \\
& Chloramphenicol & C30 \\
\hline
\end{tabular}

Сонгон шалгаруулсан бактерийн ургалтын эрчим (CFU/ml)-ийг Miles, Misra нарын аргаaр 6, 12, 24, 48, 72, 96, 120 цагийн үечлэлээр ургасан колоний тоогоор тогтоов.

Сонгон авсан бактерийн клоныг 50мкл PBS-д суспензлэн, QIAamp DNA Mini Kit ашиглан үйлдвэрлэгчийн зааврын дагуу ДНХ ялгав. Омгийн төрөл, зүйлийг тодорхойлохын тулд

\section{ҮР ДҮН}

Сонгон авсан цэвэр өсгөврүүдийг MRS шингэн тэжээлт орчинд суулган $37^{\circ} \mathrm{C}$-ийн хэмд 24 цаг анаэроб нөхцөлд өсгөвөрлөн, түрхэц бэлтгэж, Грамын аргаар будаж бичил харуураар шинжлэхэд тэгш төгсгөлтэй, ганцаар болон хоёр гурваараа заримдаа түүнээс ч олноор гинжилсэн байрлалтай, хэмжээний хувьд харилцан адилгүй урттай, таруу байрлалтай, Грам эерэг зэргээр хэлбэр зүйн хувьд сүүн хүчлийн савханцрын шинж байдлыг тогтвортой үзүүлж байв (Зураг 1).

Нян судлалын шинжилгээгээр MRS шингэн тэжээлт орчинд 24 цаг өсгөвөрлөхөд зарим өсгөврийн хувьд орчныг жигд булингартуулан, тубаны ёроолд бага зэрэг саарал өнгийн тунадас үүсгэж, зарим нь үҮл
$16 \mathrm{~S}$ p-РНХ генийг сонгон авч, 27F (5' -AGAGTTTGATCCTGGCTCAG-3'); 534R (5'-ATTACCGCGGCTGCTGG-3') праймер ашиглан ПГУ-аaр олшруулж, нуклеотидын дараалал тодорхойлсон. Нуклеотидын дарааллыг Дэлхийн ген банкин дарааллуудтай NCBI BLAST програм ашиглан, харьцуулалт хийн зүйлийг тодорхойлов.

мэт доороосоо дээш хөвсийн булингартаж өсгөвөржсөн. Өсгөвөржилтийн 48 дахь цагт хатуу тэжээлийн гадаргуу дээр тод цагаан өнгөтэй, гөлгөр тэгш захтай, дугуй хэлбэрийн колони үүсгэж байв.

Төлийн ходоод гэдэсний эмгэг төрүулэгч нянгийн эсрэг үйлчилгээг судалсан дүн: Туршилтанд Малын эмийн сорилт баталгаажуулалтын улсын лабораторид хадгалагдаж буй E. coli 09, E. coli 026, S. abortusovis 0068 дугаартай нутгийн омгуудыг ашиглав. Туршилтын дүнгээс харахад бидний ялгасан өсгөврүүд хоруу чанар өндөртэй омгуудын ургалтыг дарангуйлж байлаа (Хүснэгт 2). 

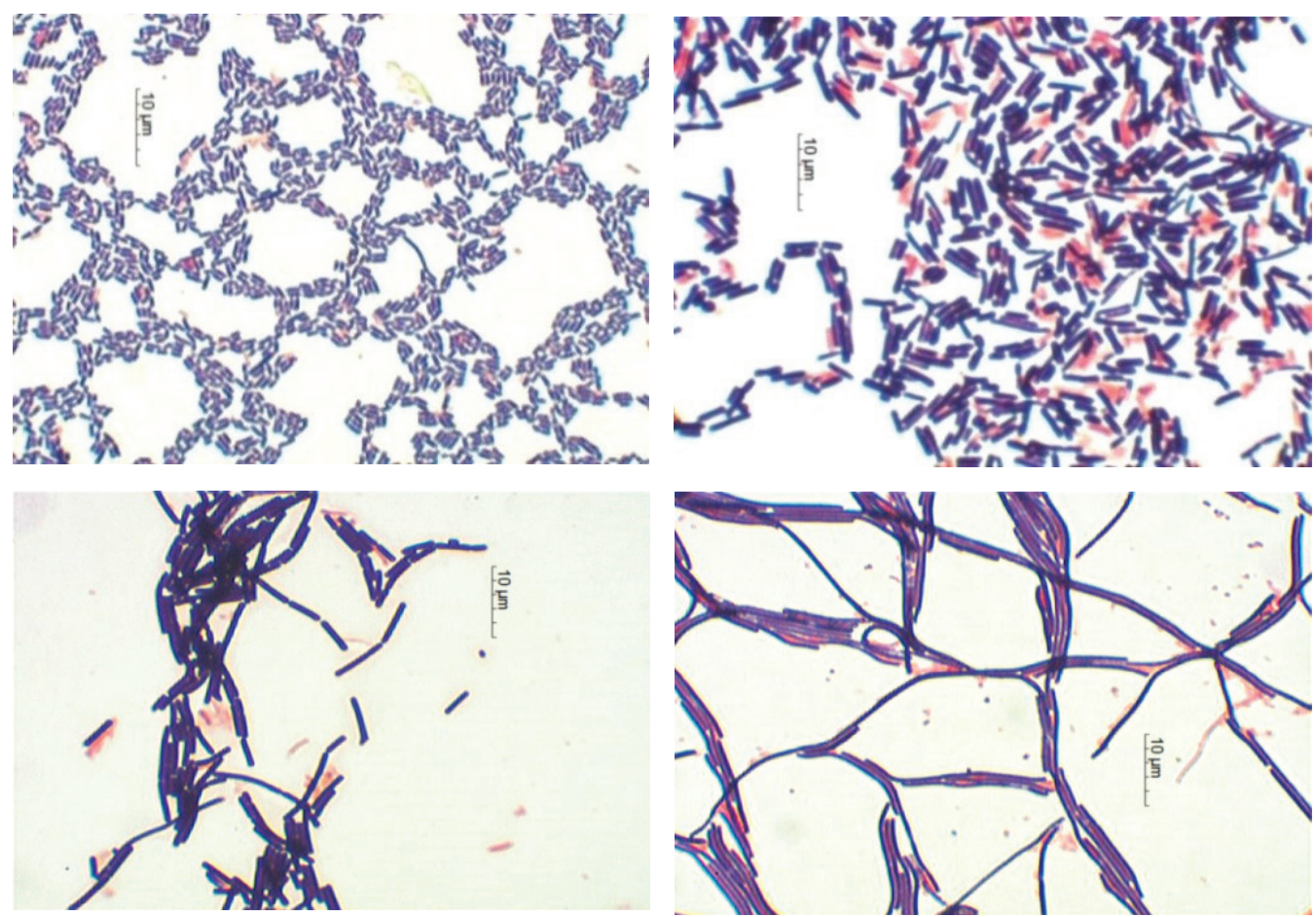

Зураг 1. Грам эерэг савханирууд $37 a, 40 c, 44 c, 65 b$

Хүснэгт 2. Цэвэр өсгөврүҮдийн малын ходоод гэдэсний эмгэг төрҮҮлэгчдэд үзүүлэх антагонист идэвхий судалсан дүн

\begin{tabular}{cccccc}
\hline \multirow{2}{*}{ № } & \multirow{2}{*}{$\begin{array}{c}\text { Өсгөвер } \\
\text { дугаaр }\end{array}$} & \multicolumn{3}{c}{ Эмгэг төрүүлэгч омгуудын ургалтыг саатуулж ариун } & \multirow{2}{*}{ бүс үүсгэсэн хэмжээ (мм) } \\
\cline { 3 - 5 } & & E. coli 09 & E. coli 026 & S. abortusovis 0068 & \\
\hline 1 & $32 \mathrm{~d}$ & 35.0 & 33.0 & 25.0 & $31.0 \pm 5.29$ \\
\hline 2 & $37 \mathrm{a}$ & 41.0 & 30.0 & 25.0 & $32.0 \pm 8.18$ \\
\hline 3 & $40 \mathrm{c}$ & 35.0 & 30.0 & 25.0 & $30.0 \pm 5.00$ \\
\hline 4 & $44 \mathrm{c}$ & 32.0 & 30.0 & 30.0 & $30.6 \pm 1.15$ \\
\hline 5 & $48 \mathrm{c}$ & 27.0 & 34.0 & 30.0 & $30.3 \pm 3.51$ \\
\hline 6 & $60 \mathrm{c}$ & 40.0 & 30.0 & 25.0 & $31.6 \pm 7.63$ \\
\hline 7 & $65 \mathrm{~b}$ & 31.0 & 36.0 & 25.0 & $30.6 \pm 5.50$ \\
\hline & $\mathrm{M} \pm \mathrm{m}$ & $34.4 \pm 4.5$ & $31.8 \pm 2.2$ & $26.4 \pm 2.2$ & \\
\hline & & & & \\
\hline
\end{tabular}

Хүчил тэсвэрлэх идэвхийг судалсан дүн: Сүүн хүчлийн бактерийн пробиотик шинж чанарын нэг үзүүлэлт нь орчныг хүчиллэг болгохын зэрэгцээ хүчиллэг орчны нөлөөг тэсвэрлэх чанар байдаг. Иймээс өсгөвөр тус бүрийн хүчил тэсвэрлэх идэвхийг $\mathrm{pH} 4.0$ болон 3.5-тай орчинд тодорхойлсон дүнг хүснэгт 3-аар харуулав. Онцлон дурьдвал 44c, 65b өсгөврүүд 93.994.8 хувийн тэсвэртэй байгаа нь тэдний ургалтанд орчны хүчиллэг нөлөөлөхгүй байгааг илтгэн харуулж байна (Хүснэгт 3). 
ХУснэгт 3. Цэвэр өсгөвруҮдийн хүчиллэг орчин тэсвэрлэх чадавхийг судалсан дүн

\begin{tabular}{|c|c|c|c|c|c|c|c|c|}
\hline \multirow[b]{2}{*}{ № } & \multirow{2}{*}{$\begin{array}{c}\text { Өсгөвөр } \\
\text { дугаар }\end{array}$} & \multicolumn{7}{|c|}{ Ургасан колонийн тоо } \\
\hline & & $\begin{array}{c}\text { A } \\
\text { pH } 6.2\end{array}$ & $\begin{array}{c}\mathrm{B} \\
\mathrm{pH} 4.0\end{array}$ & Хувь & $\begin{array}{c}\text { Анги- } \\
\text { лал }\end{array}$ & $\begin{array}{c}\mathrm{C} \\
\mathrm{pH} 3.5\end{array}$ & Хувь & $\begin{array}{c}\text { Анги- } \\
\text { лал }\end{array}$ \\
\hline 1 & $32 \mathrm{~d}$ & 333 & 313 & 93.9 & 3 & 295 & 88.5 & 3 \\
\hline 2 & $37 a$ & 250 & 244 & 97.6 & 3 & 201 & 80.4 & 3 \\
\hline 3 & $40 c$ & 262 & 238 & 90.8 & 3 & 220 & 83.9 & 3 \\
\hline 4 & $44 c$ & 249 & 235 & 94.3 & 3 & 265 & 93.9 & 3 \\
\hline 5 & $48 \mathrm{c}$ & 272 & 265 & 97.4 & 3 & 254 & 93.3 & 3 \\
\hline 6 & $60 \mathrm{c}$ & 199 & 195 & 97.9 & 3 & 184 & 92.4 & 3 \\
\hline 7 & $65 \mathrm{~b}$ & 310 & 300 & 96.7 & 3 & 294 & 94.8 & 3 \\
\hline \multicolumn{2}{|r|}{$\mathrm{M} \pm \mathrm{m}$} & $267.8 \pm 43.5$ & $255.7 \pm 40.6$ & $95.5 \pm 2.6$ & & $244.7 \pm 44.0$ & $89.6 \pm 5.5$ & \\
\hline \multicolumn{2}{|c|}{ Тайлбар: } & \multicolumn{7}{|c|}{$\begin{array}{l}\text { Ангилал } 1 \text { - В-ийн колони А-д ургасан колоний 0-30\% байвал нилээд мэдрэг } \\
\text { Ангилал } 2 \text { - В-ийн колони А-д ургасан колоний 30-80\% байвал мэдрэг }\end{array}$} \\
\hline
\end{tabular}

\section{Хүний ходоод гэдэсний эмгэг} төрүүлэгч нянгийн эсрэг үйлчилгээг судалсан дүн: Сүүлийн жилүүдэд анагаах ухааны салбарт пробиотикуудын дотроос биологийн идэвхтэй сүүн хүчлийн бактери агуулсан бэлдмэлүүдийг ходоод гэдэсний үрэвсэлт өвчин, суулгалт, дисбактериоз, хеликобактерийн гаралтай ходоодны үрэвсэлт өвчний эмчилгээнд түлхүҮ хэрэглэж эхлээд байна. Эмчилгээний мөн чанарыг анагаах ухаанд тайлбарлахдаа сүүн хүчлийн бактериуд нь гэдэсний хананд бэхлэгдэн органик хүчлүүдийг үүсгэж орчны рН-ийг хүчиллэг болгохын зэрэгцээ өөрийн биеэс бактериоцин, лактолин, ацидофилин, ацидолин зэрэг антибиотик төст үйлчилгээтэй бодисуудыг ялгаруулах замаар гэдэсний ханын барьерийг идэвхжүүлж, эмгэг төрүүлэгч нянгуудын өсөлт, үржлийг саатуулж, үржин хөгжих чадавх, байрлах орчныг нь үгүй хийдэгтэй холбон үздэг байна. Эдгээр үндэслэлүүдэд тулгуурлан ходоод гэдэсний хямрал Үүсгэдэг $S$. aureus 5695, 5068, SA27, E. coli 10963, 10977 дугаартай омгуудыг (ХӨСҮТ) ашиглан өсгөврүүдийнхээ антагонист идэвхийг судлав. Туршилтын дүнгээс харахад бидний судалж буй өсгөврүүдийн дийлэнх нь эмгэг төрүүлэгчдийн ургалтыг саатуулан 30мм-ээс дээш ариун бүс үүсгэн өсгөвөржиж буй нь тэдний үржлийг дарангуйлах чадвар сайтайг харуулсан үзүүлэлт юм (Хүснэгт 4, Зураг 2).

Хүснэгт 4. Цэвэр өсгөврүҮдийн хүний гэдэсний эмгэг төрҮүлэгчдэд УзУҮлэх антагонист идэвхийн судалгаа

\begin{tabular}{|c|c|c|c|c|c|c|c|}
\hline \multirow{2}{*}{ № } & \multirow{2}{*}{$\begin{array}{l}\text { Өсгөвөр } \\
\text { дугаар }\end{array}$} & \multicolumn{5}{|c|}{$\begin{array}{c}\text { Эмгэг төрүүлэгч омгуудын ургалтыг саатуулж ариун бүс } \\
\text { үүсгэсэн хэмжээ (мм) } \\
\end{array}$} & \multirow{2}{*}{$\mathrm{M} \pm \mathrm{m}$} \\
\hline & & $\begin{array}{l}\text { S. aureus } \\
5695\end{array}$ & $\begin{array}{l}\text { S. aureus } \\
5068\end{array}$ & $\begin{array}{l}\text { S. aureus } \\
\text { SA27 }\end{array}$ & $\begin{array}{l}\text { E. coli } \\
10963\end{array}$ & $\begin{array}{l}\text { E. coli } \\
10977\end{array}$ & \\
\hline 1 & $32 \mathrm{~d}$ & 42.0 & 30.0 & 30.0 & 37.0 & 40.0 & $35.8 \pm 5.58$ \\
\hline 2 & $37 a$ & 40.0 & 26.0 & 35.0 & 32.0 & 40.0 & $34.6 \pm 5.89$ \\
\hline 3 & $40 c$ & 45.0 & 26.0 & 35.0 & 37.0 & 40.0 & $36.6 \pm 7.02$ \\
\hline 4 & $44 c$ & 35.0 & 36.0 & 31.0 & 34.0 & 40.0 & $35.2 \pm 3.27$ \\
\hline 5 & $48 \mathrm{c}$ & 32.0 & 29.0 & 27.0 & 30.0 & 36.0 & $30.8 \pm 3.42$ \\
\hline 6 & $60 \mathrm{c}$ & 42.0 & 35.0 & 32.0 & 34.0 & 43.0 & $37.2 \pm 4.96$ \\
\hline 7 & $65 \mathrm{~b}$ & 35.0 & 29.0 & 26.0 & 27.0 & 29.0 & $29.2 \pm 3.49$ \\
\hline & $\mathrm{M} \pm \mathrm{m}$ & $38.7 \pm 4.7$ & $30.1 \pm 3.9$ & $30.8 \pm 3.5$ & $33.0 \pm 3.6$ & $38.2 \pm 4.5$ & \\
\hline
\end{tabular}



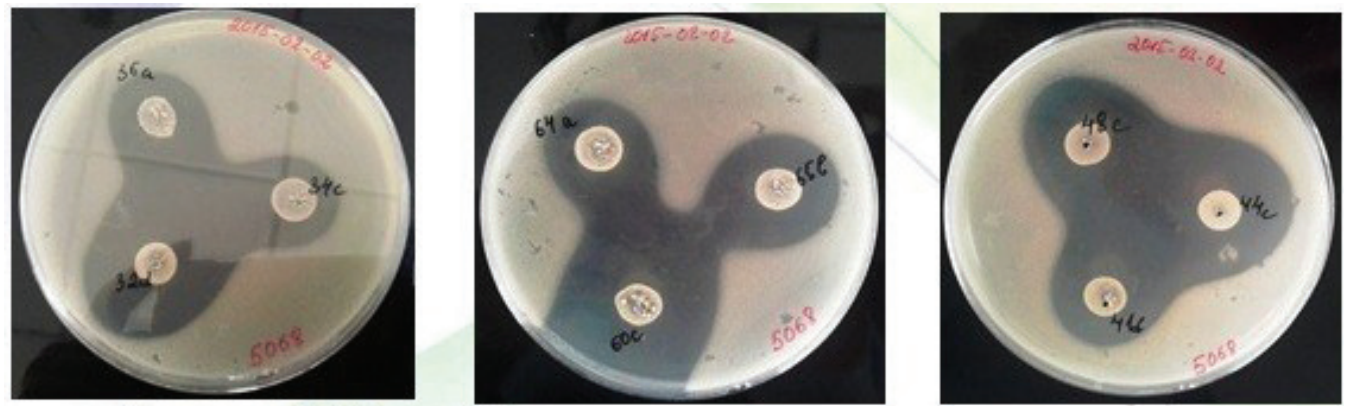

\section{S.aureus 5068 омгийн эсрэг үзүүлсэн ургалтын хүрээ}
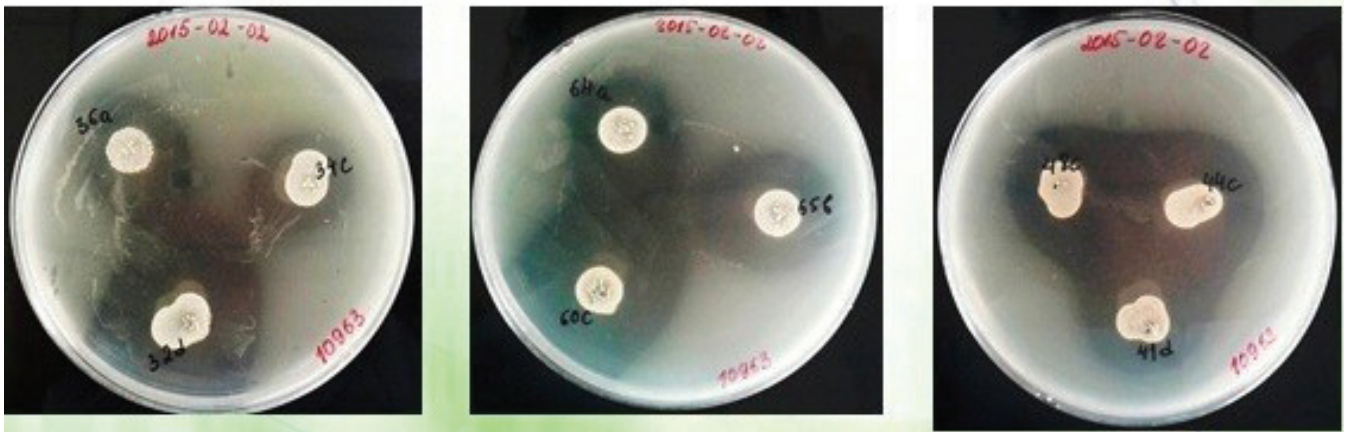

\section{E.Coli 10963 омгийн эсрэг үзүулсэн ургалтын хүрээ}

Зураг 2. Хүний ходоод гэдэсний эмгэг төруүлэгч нянгийн ургалтыг дарангуйлсан байдал

Антибиотик тэсвэрлэх чадварыг судалсан дүн: Туршилтын дүнгээс харахад өсгөвөр тус бүрийн антибиотик тэсвэрт чанар харилцан адилгүй байлаа. Онцлон дурьдвал 44c өсгөвөр ашигласан 10 төрлийн антибиотикт бусдаасаа илүҮ тэсвэртэй буюу мэдрэг бус $(9.4 \pm 0.96)$ байлаa. Харин 48c Amoxicillin (AX30), 60c Amoxicillin+Clavulanic acid (AMC30), Ampicillin+Sulbactam (SAM30) Зэрэг антибиотикт тэсвэр муутай байгаа нь тогтоогдлоо (Хүснэгт 5).

СүҮн хүчлийн бактерийн цэвэр өсгөврүудийн ургалтын эрчим (CFU/ ml)-ийг судалсан дүн: Нэгж эзэлхүүнд агуулагдах бактерийн тоог түүний ургалтын цагуудаар судлан тогтоох явдал судалгааны төдийгүй цаашилбал пробиотик бүтээгдэхүүний үйлдвэрлэл болоод үйлчилгээний цар хүрээнд нэн түрүүн шаардагдах чухал үзүүлэлтийн нэг юм. Иймд пробиотик шинж чанараараа бусдаасаа давуу байгаa L.helveticus $44 c$, L.bulgaricus $65 b$ өсгөврүүдийг сонгон ургалтын эрчмийг өсгөвөрлөснөөс хойшхи 6 цагаас эхлэн $(12,24,48,72,96)$ тодорхой цагуудаар судлан (CFU/ml) тогтооход өсгөвөржилтийн 48-72 дахь цагт өсгөврүүдийн нэгж эзэлхүүнд агуулагдах савханцрын тоо хамгийн өндөр түвшинд хүрээд 96 цагаас эхлэн буурах хандлагатай байлаа. Тухайлбал L. helveticus $44 c 48$ дахь цагт 2176x1010 CFU/ml, L.bulgaricus 65b 72 цагтаа 2503x1010 CFU/ml хэмжээнд буюу хамгийн өндөр түвшинд хүрч байв (Тахирмаг 1). 


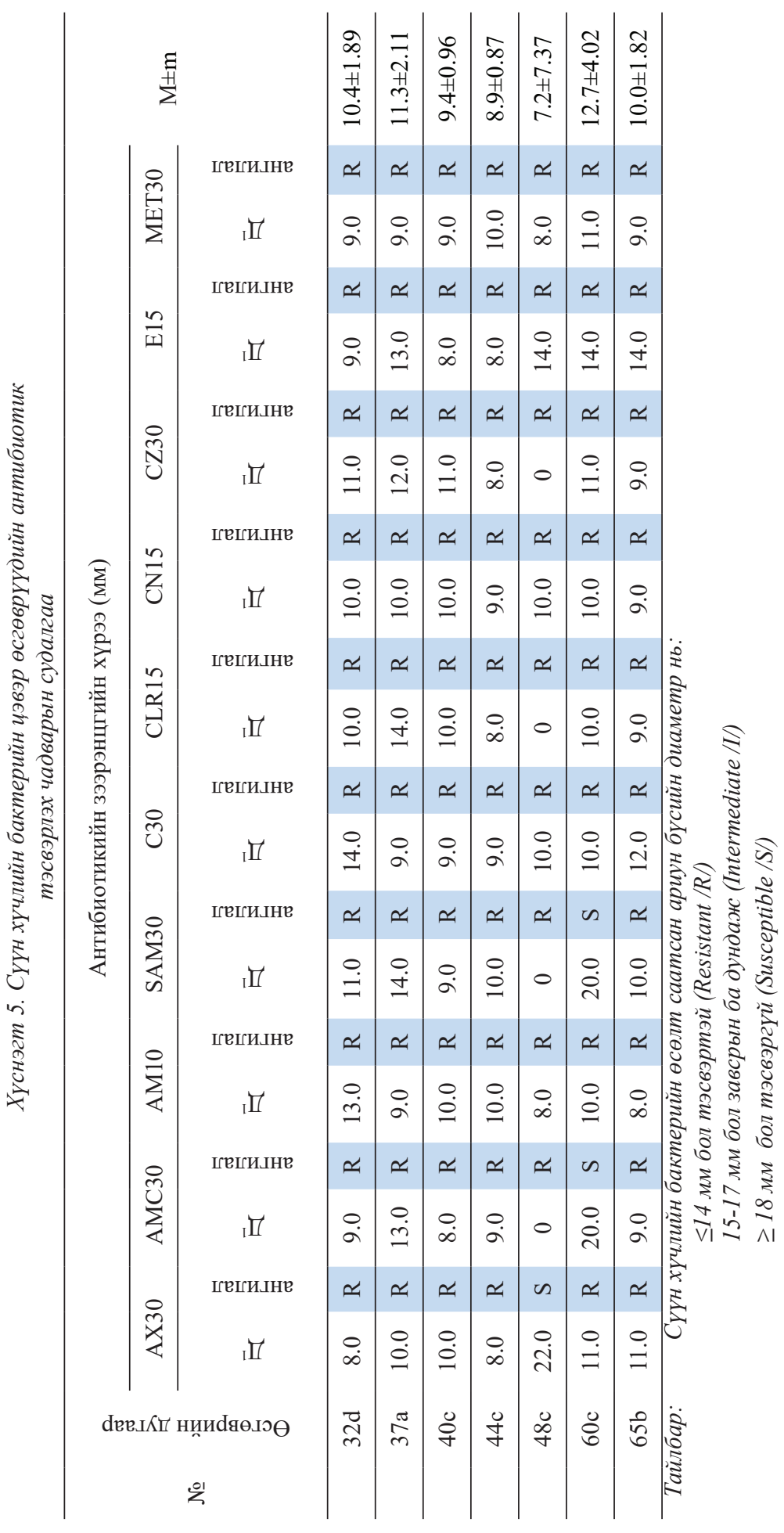




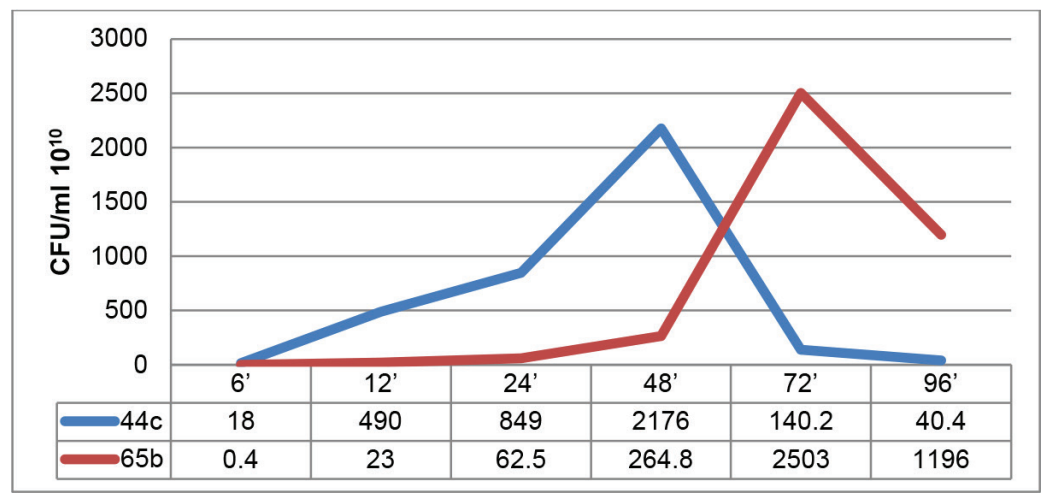

Тахирмаг 1. СүҮн хүчлийн бактерийн иэээр өсгөврүҮдийн ургалтын эрчим

Сүүн хүчлийн бактерийн зүйлийн бүрэлдэхүүн тодорхойлсон дүн: Пробиотик шинж чанараар нь сонголт хийсэн өсгөврүүдээс QIAamp DNA Mini Kit ашиглан зааврын дагуу ДНХ ялгасан. Омгийн төрөл, зүйлийг тодорхойлохын тулд $16 \mathrm{~S}$ р-РНХ генийг сонгон авч, 27F (5)-AGAGTTTGATCCTGGCTCAG-3〉); 534R (5>-ATTACCGCGGCTGCTGG-3〉) праймер ашиглан ПГУ-аaр олшруулж, нуклеотидын дараалалыг тодорхойлж NCBI BLAST програм ашиглан Дэлхийн ген банкны дарааллуудтай харьцуулалт хийн зүйлийг тодорхойлов. Судалгааны үр дүнгээс харахад 44c өсгөвөр нь Монголд айрагнаас ялгасан омог КТ368987 болох L.helveticus зүйлтэй $100 \%$, 65b өсгөвөр нь Говь-Алтай аймагт ингэний хоормогноос ялгасан омог СР016393 болох L.bulgaricus зүйлтэй 99\% төсөөтэй байлаа (Хүснэгт 6).

$16 \mathrm{~S}$ генийн ДНХ-ийн дараалалд Genetyx 6.0 болон ClustalX2 программууд ашиглан алигнмент анализ хийж, Outgroup-ээр B.subtilis (Ген банкны дугаap AL009126)ийг сонгон NJ (Neighbor Joining) алгоритм ашиглан FigTree v1.3.1 програм дээр удмын модны зураглал гаргалаа (Зураг 3).

ХУснэгт 6. Дараалал тогтоосон ДНХ-ийн хос суурийн тоо, зуйл тодорхойлсон үндэслэл,тухайн зуйлтэй төсөөтэй \%

\begin{tabular}{|c|c|c|c|c|}
\hline № & $\begin{array}{l}\text { Өсгөвөр } \\
\text { дугаар }\end{array}$ & $\begin{array}{l}\text { Бактерийн төрөл } \\
\text { зүйл }\end{array}$ & $\begin{array}{l}\text { ДНХ-ийн хос } \\
\text { суурийн тоо }\end{array}$ & $\begin{array}{c}16 \mathrm{~S} \text { генийн дарааллын хувьд тухайн зүйлтэй } \\
\text { төсөөтэй \% }\end{array}$ \\
\hline 1. & $32 d$ & L.helveticus & $521 \mathrm{bp}$ & $\begin{array}{c}99 \% \\
\text { (Монголд айрагнаас ялгасан омог КТ368991) }\end{array}$ \\
\hline 2. & $37 \mathrm{a}$ & L.helveticus & $523 \mathrm{bp}$ & $\begin{array}{c}99 \% \\
\text { (Бразилд дарснаас ялгасан омог MF191698) }\end{array}$ \\
\hline 3. & $40 \mathrm{c}$ & L.helveticus & $521 \mathrm{bp}$ & $\begin{array}{c}100 \% \\
\text { (Казахстанд бяслагнаас ялгасан омог KU555467) }\end{array}$ \\
\hline 4. & $44 c$ & L.helveticus & $521 \mathrm{bp}$ & $\begin{array}{c}100 \% \\
\text { (Монголд айрагнаас ялгасан омог КТ368987) }\end{array}$ \\
\hline 5. & $48 \mathrm{c}$ & L.bulgaricus & $519 \mathrm{bp}$ & $\begin{array}{c}100 \% \\
\text { (Тува усад уламжлалт исгэсэн сүҮн } \\
\text { бүтээгдэхүүнээс ялгасан омог КЈ026667) }\end{array}$ \\
\hline 6. & $60 \mathrm{c}$ & L.helveticus & $514 \mathrm{bp}$ & $\begin{array}{c}100 \% \\
\text { (Монголд айрагнаас ялгасан омог КТ368991) }\end{array}$ \\
\hline 7. & $65 b$ & L.bulgaricus & $518 \mathrm{bp}$ & $\begin{array}{c}99 \% \\
\text { (Говь-Алтай аймагт ингэний хоормогноос } \\
\text { ялгасан омог СР016393) }\end{array}$ \\
\hline
\end{tabular}




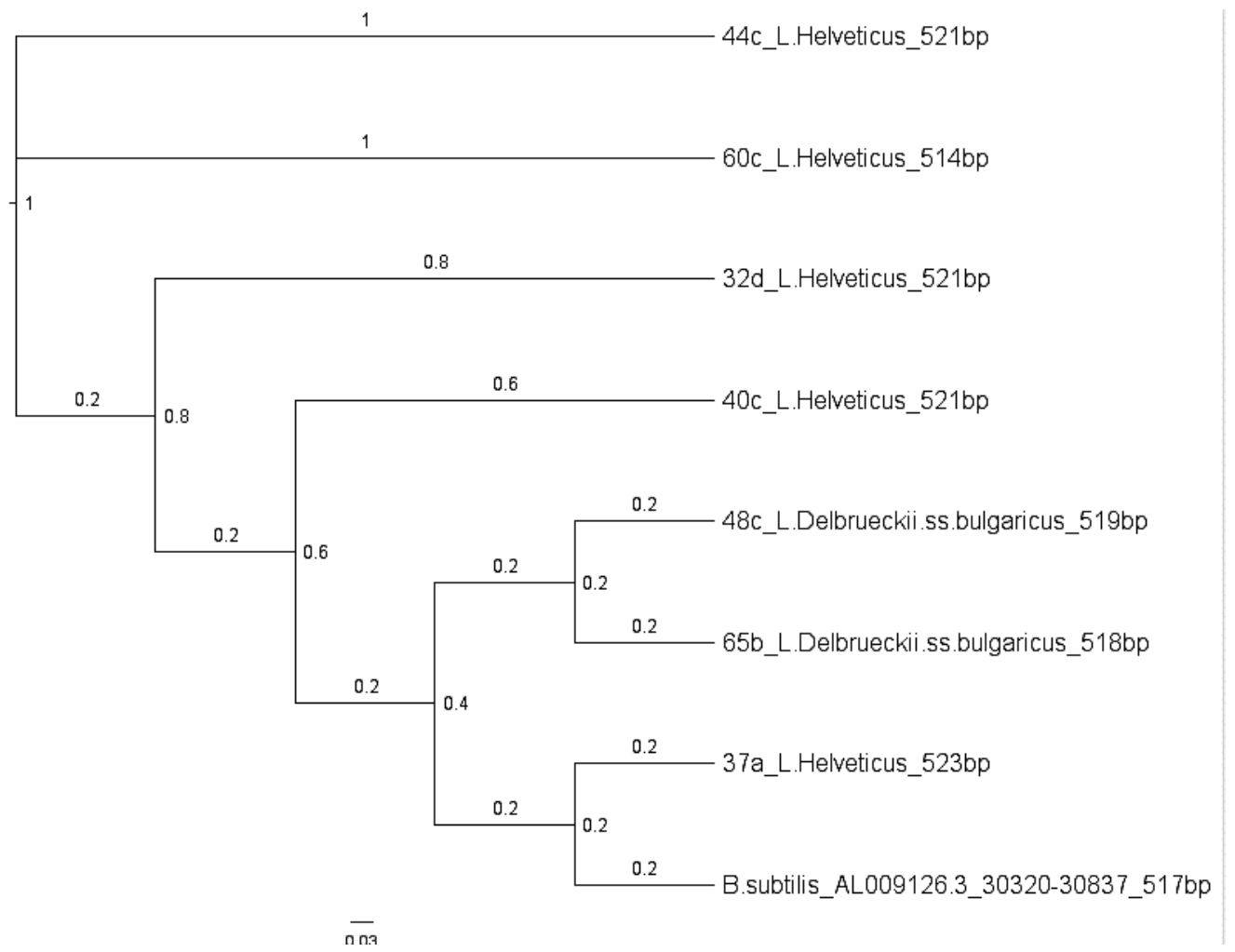

Зураг 4. СҮҮн хүчлийн бактерийн удмын модны зураглал

\section{ХЭЛЦЭМЖ}

Сүүн хүчлийн бактери нь өөрийн биеэс антибиотик төст бодис (бактериоцин, лактолин, низин г.м) ялгаруулан [Batdorj et al., 2006] эмгэг төрүүлэгч бактериудын үржлийг саатуулан тэдгээрийн үүсгэсэн хортой бодисын цусанд шимэгдэх явцыг сааруулах үйлчилгээтэй [Рожерс, 1928, Квасников, 1975, Антипов, 1980, Тимошко, 1980, Sanai Okada 2003] бөгөөд шим тэжээлийн бодисын нийлэгжлийг сайжруулах замаар тэжээл боловсруулалтыг засан идэвхжүүлж бие махбодын уураг, нүүрс ус, витамины хангамжийг дээшлүүлдэг [Дэмбэрэл ба Дүгэрсүрэн, 2003] гэсэн судлаачдын дүгнэлтийг бидний зүгээс пробиотик бактериудын үйлчилгээний гол үнэлэмж гэж үзсэн юм. Ийм ч учраас уул зарчмыг баримтлан судалж буй өсгөврүүдийнхээ антагонист идэвхийг төлийн (E. coli 09, E. coli $026, S$. abortusovis 0068) болон хүний ( $S$. aureus 5695, S. aureus 5068, S. aureus SA27, E. coli 10963, E. coli 10977) ходоод гэдэсний эмгэг төрүүлэгч нянгуудын эсрэг үйлчилгээгээр үнэлсэн билээ. Туршилтын дүнд бидний ялган авсан L.helveticus 44c, L. bulgaricus 65 b зүйлийн савханцрууд нь хүн, малын ходоод гэдэсний эмгэг төрүүлэгчдийн ургалтыг бүрэн дарангуйлсан нь ашигтай бактерийн гол шинжийг харуулсан үзүүлэлт болно.

Орчны $\mathrm{pH}-ы н$ өөрчлөлт нь микроорганизмын ферментийн идэвхт нөлөөлснөөр түүний эсийн дотор явагдах биохимийн урвалуудын хурд, чиглэлийг өөрчилдөг. Орчны $\mathrm{pH}$ өөрчлөгдөхөд эсийн гадаргуугийн цахилгаан цэнэг хувирч зарим төрлийн ионуудын шилжилт зогсох ба бактерийн эсийн цитоплазмын 
мембраны сонгон нэвтрүүлэх шинж чанарт ч өөрчлөлт [Hassan Hassanzadazar 2012, Johanningsmeier SD 2012] ордог. Ингэснээр микроорганизмын бодисын солилцооны хэвийн үйл ажиллагаа алдагддаг. Микроорганизмын зүйл тус бүрийн

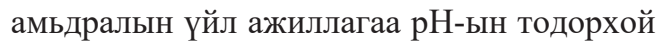
хязгаарт хэвийн явагдана. Тухайлбал, ихэнх дрожж, хөгц мөөгөнцрийн үржих хамгийн тохиромжтой орчны $\mathrm{pH}$ нь 5-6 орчим байдаг бол бактериуд сулавтар хүчиллэг буюу саармагдуу ( $\mathrm{pH}=6.8-7.3)$ орчинд сайн өсөж үржинэ. Харин хөгц мөөгөнцрүүд орчны рН-ын өөрчлөлтийн өргөн хүрээнд $(1<\mathrm{pH}<11)$ амьдардаг байна.

Сүүн хүчлийн бактерийн пробиотик шинж чанарын нэг үзүүлэлт нь орчныг хүчиллэг болгохын зэрэгцээ хүчиллэг орчны нөлөөг тэсвэрлэх [Jie Yu, Wa Gao, Manjun Qing, Zhihong Sun 2012] мөн хоол боловсруулах замаас ялгарах шүүрэл тухайлбал цөсний хүчлийн нөлөөнд тэсвэртэй [Hassan Hassanzadazar 2012, Johanningsmeier SD 2012] байх явдал юм. Бидний судалгаагаар сонгон шалгаруулсан сүүн хүчлийн савханцруудын хүчил тэсвэрлэх идэвхийг $\mathrm{pH} 4.0$ болон 3.5тай орчинд тодорхойлоход уг өсгөврүүд бүрэн тэсвэртэй байлаа. Өөрөөр хэлбэл өсгөвөр 32d, 44c, 48c хувьд 88.5-аас дээш хувийн колони ургаж байгаа нь тэдний ургалтанд орчны хүчиллэг нөлөөлөхгүй байгааг илтгэж байна. Эдгээр шинж чанар нь тухайн өсгөврүүдийг эмчилгээ сэргийлэлтийн зориулалтаар ашиглах пробиотик бүтээгдэхүүний эх материалаар сонгох бүрэн боломжтойг харуулж байгаа чухал үзүүлэлтийн нэг юм.

Сүүн хүчлийн савханцруудын эмчилгээ сэргийлэлтийн ач холбогдлыг үнэлэх чухал шалгууруудын нэг бол тэдгээрийн антибиотикийн үйлчлэлд тэсвэртэй байх чанар буюу эмийн эмчилгээтэй хослон хэрэглэх боломжийг илрүүлэх явдал юм. Энэ үзэл баримтлалын үүднээс сүүн хүчлийн савханцруудын антибиотикийн үйлчлэлд хэр зэрэг тэсвэртэй, цаашилбал ямар антибиотиктой хавсран хэрэглэх боломжтойг тодорхойлохыг чухалчилсан билээ [Demberel Sh, Dugersuren J 2016, Khandsuren B 2013, Gamal Fadl M 2014]. Энэ чиглэлээр явуулсан туршилтын дүнгээс харахад 10 төрлийн антибиотикийн зээрэнцэг L.helveticus $44 c \quad 8.9 \pm 0.87$ мм, L.helveticus 40 c $9.4 \pm 0.96 \mathrm{MM}$, L. bulgaricus $65 b 10.0 \pm 1.82$ мм-ийн хүрээ үүсгэж байлаа. Энэхүу үр дүн нь эдгээрийг эмчилгээ сэргийлэлтийн зориулалтаар дангаaр нь болон дээрх антибиотиктой хавсран хэрэглэх боломжтойг харуулж байна.

Өсгөврүудийн нэгж эзэлхүүнд агуулагдах бактерийн тоог түүний өсгөвөржиж буй цагуудаар судлан тогтоох явдал судалгааны төдийгүй цаашилбал пробиотик бүтээгдэхүүний үйлдвэрлэлийн технологи болон хэрэглээний шийдлийг боловсруулахад нэн түрүүн шаардагдах зүйл юм. Иймээс бүх шинж чанараараа бусдаасаа давуу байсан L.helveticus 44c, L.bulgaricus $65 b \quad$ өсгөврүүдийн нэгж эзэлхүүнд агуулагдах бактерийн тоог өсгөвөрлөснөөс хойшхи 6 цагаас эхлэн (12, $24,48,72,96)$ тодорхой цагуудаар судлан (CFU/ml)-ийг тогтооход өсгөвөржилтийн 48-72 дахь цагт хамгийн өндөр түвшинд хүрч 96 цагаас эхлэн буурах хандлагатай байлаа. Тухайлбал L. helveticus $44 c$ ургалтын 48 дахь цагт 2176x1010 CFU/ml, L.bulgaricus 65 b 72 дахь цагтаа $2503 \times 1010$ $\mathrm{CFU} / \mathrm{ml}$ хэмжээнд хүрч байгаа нь пробиотик бүтээгдэхүүнд ашиглах омгийн шаардлагад бүрэн нийцэж байлаа. Үүнээс үзвэл тэдгээрийг пробиотик бүтээгдэхүүний эх материал болгон ашиглахад үйлчилгээний идэвх 24-72 цагтаа өндөр түвшинд хүрэх магадлалыг харгалзах шаардлагатай ажээ.

Судалгааны явцад гарган авсан L.helveticus 44c, L.bulgaricus $65 \mathrm{~b}$ өсгөврүүдийн монголд өргөн тархсан хүн, малын ходоод гэдэсний эмгэг төрүүлэгч омгуудын эсрэг идэвхтэй үйлчилгээ ҮзҮҮлэхийн зэрэгцээ хоол боловсруулах замын шүүрлийн үйлчлэл болон антибиотикийн нөлөөг сайтар тэсвэрлэж, 
хадгалалтын явцад шинж чанараа алдахгүй байгаа зэрэг үндэслэлүүд нь тэдгээрийг пробиотик бүтээгдэхүүний үйлдвэрлэлийн технологид ашиглах боломжийг бидэнд олгож байна.

\section{ДҮГНЭЛТ}

1. Монгол Алтайн нурууны Казах үндэстний уламжлалт исгэлэн сүүн бүтээгдэхүүнээс ялгасан сүүн хүчлийн бактериуд нь гэдэсний эмгэг төрүүлэгчдэд Үзүүлэх антагонист идэвх, антибиотикийн үйлчилгээг болон хүчиллэг орчинг тэсвэрлэх чанар сайтай байгаа нь тогтоогдлоо.

2. L. helveticus $44 c$, L.bulgaricus $65 b$ өсгөврүүд нь антибиотиктэй хослох, монголд өргөн тархсан хүн, малын ходоод гэдэсний эмгэг төрүүлэгч омгуудын эсрэг үйлчилгээтэй, ходоод гэдэсний хүчил шүлтийн нөлөөнд тэсвэртэй зэрэг шинж чанарт тулгуурлан эдгээрийг зохицуулах үйлчилгээтэй хүнс буюу пробиотик бүтээгдэхүүний үйлдвэрлэлд ашиглах боломжтой гэж үзэж байна.

\section{НОМ ЗYЙ}

1. Demberel Sh, Dugersuren J, Koichi Watanabe "Diversity of Lactic acid bacteria and yeasts in the Mongolian traditional fermented milk products is a rich sourse for probiotic strains". ХIX Международнаянаучно-практическая конференция «Аграрная наука - сельскохозяйственному производству Сибири, Казахстана, Монголии, Беларуси и Болгарии» 19-21 Окт., Беларусь, 2016 г.Минск 139

2. Khandsuren B, Dugersuren J, Demberel Sh, "Results of the study on antagonistic effects of pure isolates of Lactic Acid Bacteria from fermented mares milk starter" Аграрная наукасельсксохозяйственному производству Монголии, Сибирского региона, Казахстана и Болгарии, 29-30 МАЯ 2013 г. Улаанбаатар, 124-125 cmp

3. http://textbookofbacteriology.net/lactics.html

4. Jie Yu, Wa Gao, Manjun Qing, Zhihong Sun "Identification and characterization of lactic acid bacteria isolated from traditional pickles in Sichuan, China, J. Gen. Appl. Microbiol., 58, $163 \square 172$ (2012)

5. Batdorj B, Dalgalarrondo M,Choiset $Y$, et.al "Purification and characterization of two bacteriocins produced by lactic acid bacteria isolated from Mongolian airag", 2006 Oct https:// www.ncbi.nlm.nih.gov/pubmed/16968295

6. http://microbiologyscience.blog.gogo.mn/read/entry452071

7. Hassan Hassanzadazar, Ali Ehsani,Karim Mardani, and Javad Hesari "Investigation of antibacterial, acid and bile tolerance properties of lactobacilli isolated from Koozeh cheese" 2012. https://www.ncbi.nlm.nih.gov/pmc/articles/PMC4299980/

8. Johanningsmeier SD, Franco W, Perez-Diaz, McFeeters RF."Influence of sodium chloride, $\mathrm{pH}$, and lactic acid bacteria on anaerobic lactic acid utilization during fermented cucumber spoilage" J Food Sci. 2012 Jul;77(7):M397-404. doi: 10.1111/j.1750-3841. 2012.02780.x https://www.ncbi.nlm.nih.gov/pubmed/22757713

9. Adamberg K, Kask S, Laht TM, Paalme T. "The effect of temperature and $p H$ on the growth of lactic acid bacteria: a pH-auxostat study" Int J Food Microbiol. 2003 Aug 15;85(1-2):171-83. https://www.ncbi.nlm.nih.gov/pubmed/12810281

10. Gamal Fadl M. Gad, Ahmed M. Abdel-Hamid, Zeinab Shawky H. Farag "Antibiotic resistance in lactic acid bacteria isolated from some pharmaceutical and dairy products" Braz J Microbiol. 2014; 45(1): 25-33. https://www.ncbi.nlm.nih.gov/pmc/articles/PMC4059307/ 


\title{
STUDY ON PROPERTIES OF LACTIC ACID BACTERIA ISOLATED FROM FERMENTED DAIRY PRODUCTS
}

\author{
Khandsuren $B^{1 *}$, Demberel $\mathrm{Sh}^{2}$, Dugersuren $J^{2}$ \\ 1- School of Veterinary Medicine, Mongolia \\ 2-Institute of Veterinary Medicine, Mongolia \\ *corresponding author: e-mail: khanduul@yahoo.com
}

\begin{abstract}
We isolated lactic acid bacteria from fermented dairy products, fermented mare's milk and cow yogurt, which are traditionally produced by Mongolian herders, and carried out in vitro study of their probiotic properties. Culture $44 \mathrm{c}$ is $100 \%$ identical to species Lactobacillus helveticus (Lhelveticus) or a strain KT368987, isolated from Mongolian airag, while culture $65 \mathrm{~b}$ is $99 \%$ identical to Lactobacillus delbreuckii subsp. bulgaricus (L.bulgaricus) or strain CP016393 isolated from camel fermented milk in Gobi-Altai aimag and characteristics of both cultures were the best among all cultures obtained in the present study. Isolated lactic acid rods completely inhibited the growth of gastro-intestinal pathogens which spread among livestock (E.coli 09, E.coli 026, S.abortusovis 0068) and Mongolian population (S.aureus 5695, S.aureus 5068, S.aureus SA27, E.coli 10963, E.coli 10977). As well as, we determined the properties, including resistance to the acidic environment of digestive tract and activity when using with common antibiotics, which are the basic requirements for bacterial strains used in functional food production.

According to the result, when $\mathrm{pH}$ of the environment reached 3.5 or 4.0, growth rate of the strains was over 80 percent and the lactic acid strains were variably resistant to 10 antibiotics of 5 classes (penicillin, aminoglycoside, cephalosporin and macrolide). For example; Formation of $8.9 \pm 0.87 \mathrm{~mm}$ zone around all antibiotic discs for culture $44 \mathrm{c}$ of L.helveticus demonstrates the culture can be used in combination with these antibiotics for therapeutic purposes. Besides of these characteristics, CFU per $\mathrm{ml}$ was determined by growing on MRS nutrient medium under anaerobic condition. Moreover, $\mathrm{CFU} / \mathrm{ml}$ was determined because its spectrum of activity depends on the number of bacteria per $1 \mathrm{ml}$. L.helveticus $44 \mathrm{c}$ reached its highest volume $\left(2503 \times 10^{10}\right)$ at $48^{\text {th }}$ hour of growth, while L.bulgaricus $65 \mathrm{~b}$ reached its highest volume $\left(2503 \times 10^{10}\right)$ at $72^{\text {th }}$ hour of growth. After they reached their highest volume, both of them tended to decrease. For this reason, these strains, especially L.helveticus $44 c$ and L.bulgaricus $65 b$ strains, are possible to be used as a source material for probiotics or functional food products.
\end{abstract}

Keywords: Lactic acid bacteria, probiotic, antagonist activity, L. helveticus, L. delbrueckiis ssp. bulgaricus; 